\title{
Assessment of the treatment of chronic hepatitis C in the state of Mato Grosso, central Brazil
}

\author{
Francisco Kennedy Scofoni Faleiros de Azevedo', \\ Cassius Clay Scofoni Faleiros de Azevedo², Francisco José Dutra Souto ${ }^{1 /+}$
}

${ }^{1}$ Hospital Universitário Júlio Muller, Universidade Federal de Mato Grosso, Rua Luis Philippe Pereira Leite s/n, 78048-902 Cuiabá, MT, Brasil ${ }^{2}$ Pronto Socorro Municipal de Várzea Grande, Várzea Grande, MT, Brasil

In Brazil, the treatment of hepatitis C virus (HCV) infection is funded by the national public health system (SUS). To evaluate treatment results in the state of Mato Grosso, central Brazil, we have consulted the files of the office of the State Department of Health responsible for supplying such medications. We obtained information on 232 treatments of 201 patients who underwent treatment in or prior to 2008. The study was conducted by reviewing medical records, making telephone calls and interviewing the assistant physicians. Thirty-nine patients (19.4\%) had cirrhosis and HCV genotype 1 predominated (64.3\%). Excluding patients with comorbidities or treatment without ribavirin we analysed 175 treatments (sustained virologic response occurred in $32.6 \%$ of cases). Twenty-six of these 175 were retreatments and the sustained virological response (SVR) rate among them was 30.8\%; the SVR rate was 32.9\% among those receiving treatment for the first time. The SVR rate of genotype 1 patients was $27.8 \%$, whereas it was $37.5 \%$ in non-1 genotype patients. The adjusted multivariate analysis showed association of SVR with the absence of cirrhosis [odds ratio (OR): 7.7; confidence interval (CI) 95\%: 2.5, 33.3], the use of pegylated interferon (OR: 5.8; CI 95\%: 1.5, 21.4), non-1 genotype (OR: 5.3; CI 95\%: 1.7, 16.7) and uninterrupted treatment (OR: 9.0; CI 95\%: 3.3, 45.4). The SVR rates were similar to those found in other Brazilian studies about HCV, but lower than those found in national and international clinical trials. These data suggest that the treatments of chronic hepatitis $C$ that are made available by SUS does not, under normal conditions, work as well as the original controlled studies indicated.

Key words: chronic hepatitis C - treatment - pegylated interferon - ribavirin conventional interferon - sustained virological response

The hepatitis $\mathrm{C}$ virus (HCV) is one of the main causes of chronic hepatitis worldwide and is responsible for a large percentage of cases of cirrhosis and hepatocellular carcinoma as well as referrals for liver transplant (Kim 2002, Thomas \& Seeff 2005, Ghany et al. 2009).

Starting in the 1990s, the treatment of chronic hepatitis $\mathrm{C}$ with medication was able to change the history of the disease, thus avoiding its complications (Ghany et al. 2009). The first medication used was [conventional interferon- $\alpha(\mathrm{IFN}-\alpha)(\mathrm{IFNc})]$, which was successful in fewer than $20 \%$ of cases (Davis et al. 1989). Later, the combination of IFNc with ribavirin (RBV) increased the chances of a sustained virological response (SVR), which denotes the absence of detectable HCV RNA in the plasma for at least six months after treatment is concluded in approximately $35-40 \%$ of cases (Poynard et al. 1998). In early 2000, the pegylation process allowed an increase in the half-life of IFN- $\alpha 2 \mathrm{a}$ and $2 \mathrm{~b}$ (PEG-IFN) (Manns et al. 2001, Fried et al. 2002). Currently, close to half of all cases reach SVR when PEG is combined with RBV (Hadziyannis et al. 2004).

Financial support: CNPq (to FJDS)

+ Corresponding author: fsouto@terra.com.br

Received 3 June 2011

Accepted 24 October 2011
In North America and Europe, $\mathrm{HCV}$ is treated with PEG-IFN and RBV for six months (for genotypes 2 and 3 ) or for 12 months (for genotype 1). In Brazil, the Ministry of Health [through the national public health system (SUS)] provides these medications free of charge, but limits the prescription of PEG-IFN to genotype 1, supplying IFNc for the treatment of other genotypes (pursuant to Administrative Rule 34 of 28 September 2007). This practice is based on a multicentre clinical trial of one of the pegylated IFNs on the market (2b), which suggested that there was no statistically significant difference between PEG-IFN and IFNc combined with RBV for genotypes 2 and 3 (Manns et al. 2001).

It is possible to attain SVR using PEG-IFN and RBV in patients in whom previous therapy with IFNc and RBV for chronic hepatitis had failed. Sherman et al. (2006) demonstrated SVR in $43 \%$ of relapsing patients in whom RNA-HCV suppression was achieved during treatment, but who tested positive again after the medication was discontinued and in $32 \%$ of patients who did not respond to IFNc plus RBV.

Despite the evolution of treatment, there are still obstacles for its application on a large scale, such as the high cost of the recommended drugs and the high incidence of side effects. This treatment is contraindicated for patients with decompensated cirrhosis, thrombocytopenia or neutropenia, serious heart diseases or mental illnesses.

In the past few years, some studies have been published in the Brazilian medical literature describing the experiences of different healthcare service providers 
with the treatment of chronic hepatitis $\mathrm{C}$ in Brazil (Alves et al. 2003, Figueiredo-Mendes et al. 2003, Acras et al. 2004, Brandão et al. 2006, Gonçales et al. 2006, 2010, Parise et al. 2006, Silva et al. 2007, Vigani et al. 2008, Almeida et al. 2009). These reports include experiences in the South and Southeast Regions of the country. The purpose of the present study is to describe and analyse the results of the treatment of chronic hepatitis $\mathrm{C}$ in the state of Mato Grosso (MT), as there are no known reports of this type for the Central-West Region of Brazil.

\section{PATIENTS, MATERIALS AND METHODS}

Upon reviewing the lists of treatment authorised by the Farmácia de Alto Custo (FAC), the government-run pharmacy for the distribution of high-cost drugs of the Mato Grosso State Department of Health (SSEMT), we identified a total of 268 patients treated between 2002-2008. As there is no public health unit specifically designated to manage IFN injections in MT, these medications are delivered directly to the patients, who are then personally responsible for administering the injections. Consequently, there are no official records in FAC files indicating whether these treatments were completed or successful. To gather patient information, we sought the help of the assisting physicians who had ordered the medications. We asked the permission of these physicians to access the medical records of their patients at the respective clinics and healthcare centres; we also obtained permission from the directors of each medical institution.

We sought information regarding the demographics of the patients, the characteristics of the cases, such as the genotype and the kind of IFN- $\alpha$ prescribed and the outcomes of the treatments. Whenever available, the results of the liver biopsies were expressed using the METAVIR score for fibrosis and inflammatory activity (Bedossa \& Poynard 1996).

The outcome of interest (the SVR) was defined as non-detection of HCV RNA for at least six months after the conclusion of treatment. Patients who stopped the treatment before the recommended schedule due to side effects, intolerance or problems caused by periods of irregularity of drug delivery from the public health service were classified as "having interrupted the treatment".

The data obtained were stored using the software EpiInfo 6.04d (Centers for Disease Control and Prevention, Atlanta, USA). Appropriate statistical tests were performed to compare continuous and categorical variables, with respective dispersion and a confidence interval (CI) of $95 \%$, using the same software. A logistic regression model was created to analyse the association of SVR with the variables related to it according to univariate analysis. Classical variables were also included in the model, even if they were not associated with SVR in univariate analysis. For this analysis, a stepwise method was used in Stata 8.2 (Stata Corporation, College Station, Texas, USA, 2005).

The ethical aspects of the project were analysed and approved on 15 April 2009, by the Research Ethical Committee of the University Hospital Julio Muller of the Federal University of Mato Grosso under protocol 599/08.

\section{RESULTS}

Of the 268 individuals registered at the FAC who requested medication for the treatment of chronic hepatitis C from 2002-2008 we obtained information on 201 patients corresponding to 232 initial treatments and 31 retreatments. We were only able to recover the outcomes of 197 treatments. The majority of these treatments $(52.6 \%)$ took place in public health institutions.

Of the 201 individuals, 145 (72.1\%) were male (Table I). The average age of the 201 patients at the beginning of treatment was 48 years old ( 46 for male patients and 50 for female patients). The average age of the 31 patients who underwent retreatment was 51 . The majority of the patients were Caucasians, but there were a large proportion of individuals with a mix of European, African and Native South American ancestries. The difficulty of classifying the ethnicities of participants prevented any outcomes analysis that included ethnicity as a variable.

We were able to recover information on the $\mathrm{HCV}$ genotypes of 157 patients (77.6\%). Genotype 1 was responsible for the largest number of cases (101, 64.3\%), followed by genotype 3 (46 cases, 29.3\%). It was not possible to recover information on the dosage of RBV used in a large number of the patients. Most of the patients received $1 \mathrm{~g}$ daily, but data on dosage reduction was scarce. Therefore, we were unable to analyse the effects of this important variable on the final result of the treatment.

Of the 197 treatments with recovered results, SVR was present in $30.9 \%$ of them $(\mathrm{CI} 95 \%=24.6-38 \%)$. Be-

\section{TABLE I}

Characteristics of the 201 patients who underwent treatment for chronic hepatitis $\mathrm{C}$ in the state of Mato Grosso, Brazil, from 2002-2008, with medication supplied by public health

\begin{tabular}{c} 
Total \\
$\mathrm{n}(\%)$ \\
\hline
\end{tabular}

Total 201

\section{Gender}

Male $\quad 145(72.1)$

Female

$56(27.9)$

Age (average, extremes)

$48(16-68)$

Initial treatments

$201(86.6)$

Retreatments

$31(13.4)$

Know genotype

1

2

$157(78.1)$

$101(64.3)$

$9(5.7)$

$46(29.3)$

3

$1(0.7)$

Unknown $44(21.9)$

Cirrhosis $39(19.4)$

Fibrosis stage $^{a} \quad 71(35.3)$

$0-2 \quad 24(50.7)$

$3-4 \quad 47(49.3)$

a: classification according to Metavir (Bedossa \& Poynard 1996). 
cause some of these patients had not received a therapeutic scheme with RBV due to contraindication (renal failure and dialysis treatment) and because some of the patients were co-infected with HIV, we did not include these patients to better compare the results with those of other reports and trials. Therefore, 149 patients (26 of whom were retreatments) who received 175 treatments with IFN- $\alpha$ (IFNc or PEG-IFN) and RBV were included in the study. The global SVR in this group was $32.6 \%$. For patients who received PEG-IFN the SVR was $35.3 \%$ and for patients who received IFNc, the SVR was 27.1\% $(\mathrm{p}=0.353)$. The SVR rates were slightly higher for the patients undergoing initial treatments $(32.9 \%)$ than for those undergoing retreatment $(30.8 \%, \mathrm{p}=0.831)$ and they were also higher in patients infected by a non-1 genotype $(37.5 \%)$ than in those infected by genotype $1(27.8 \%$, p $=0.295$ ). Regarding only the patients infected by non-1 genotypes, there was a better response to the use of the combination of PEG-IFN and RBV compared to the com- bination of IFNc and RBV (52.9\% vs. $20.9 \%$, p $=0.034)$ (Table II). Eighty-seven (75\%) of 116 treatments with PEG-IFN were performed with PEG-IFN- $\alpha 2 \mathrm{a}$. Because there were few treatments (25\%) with PEG-IFN- $\alpha 2 b$, comparison between the products was not possible.

Thirty-four $(23.8 \%)$ of 143 patients had cirrhosis (data unavailable for 6 patients) at the beginning of the treatment and they were diagnosed through histopathology or through clinic and laboratory data. They corresponded to 46 treatments and retreatments and $15.2 \%$ had SVRs.

Multivariate analysis showed that infection by non-1 genotypes, the use of therapeutic schedules employing PEG-IFN, non-interruption of treatment and the absence of cirrhosis were independent factors associated with SVR (Table III). The outcome was not influenced by the patient's gender or age, whether the patient was treated at public or private healthcare facilities, or whether the patient was undergoing first treatment or retreatment.

\section{TABLE II}

Results of the 175 treatments with ribavirin (RBV) carried out in patients without human immunodeficiency virus infection or chronic renal failure, regarding type of interferon used, whether it was the initial treatment or retreatment, and genotype

\begin{tabular}{|c|c|c|c|}
\hline & $\begin{array}{c}\text { Total } \\
\mathrm{n}\end{array}$ & $\begin{array}{l}\text { SVR } \\
\text { n (\%) }\end{array}$ & $\mathrm{p}$ value \\
\hline Total & 175 & $57(32.6)$ & - \\
\hline Initial treatments & 149 & $49(32.9)$ & - \\
\hline Retreatments & 26 & $8(30.8)$ & 0.831 \\
\hline Genotype 1 & 90 & $25(27.8)$ & - \\
\hline Genotype other than 1 & 56 & $21(37.5)$ & 0.218 \\
\hline Unidentified genotype & 29 & $11(37.9)$ & 0.300 \\
\hline All treatments of cirrhotic patients & 46 & $7(15.2)$ & - \\
\hline All treatments of non-cirrhotic patients & 123 & $49(39.8)$ & 0.004 \\
\hline Therapy regimen with PEG-IFN and RBV & 116 & $41(35.3)$ & - \\
\hline Therapy regimen with IFNc and RBV & 59 & $16(27.1)$ & 0.272 \\
\hline Initial treatments with PEG-IFN and RBV & 93 & $33(35.5)$ & - \\
\hline Initial treatments with IFNc and RBV & 56 & $16(28.6)$ & 0.384 \\
\hline Retreatments with PEG-IFN and RBV & 23 & $8(34.8)$ & - \\
\hline Retreatments with IFNc and RBV & 3 & $0(0)$ & $0.219^{a}$ \\
\hline \multicolumn{4}{|l|}{ Genotype $1(n=90)$} \\
\hline Treatments with PEG-IFN and RBV & 78 & $23(29.4)$ & - \\
\hline Treatments with IFNc and RBV & 12 & $2(16.7)$ & 0.355 \\
\hline Initial treatments & 77 & $22(28.6)$ & - \\
\hline Using PEG-IFN and RBV & 66 & $20(30.3)$ & - \\
\hline Using IFNc and RBV & 11 & $2(22.2)$ & $0.497^{a}$ \\
\hline Retreatments & 13 & $3(23.1)$ & - \\
\hline Using PEG-IFN and RBV & 12 & $3(25)$ & - \\
\hline \multicolumn{4}{|l|}{ Non-1 genotype $(\mathrm{n}=56)$} \\
\hline Treatments with PEG-IFN and RBV & 17 & $9(52.9)$ & - \\
\hline Treatments with IFNc and RBV & 39 & $8(20.9)$ & 0.034 \\
\hline Initial treatments & 44 & $17(38.6)$ & - \\
\hline Using PEG-IFN and RBV & 7 & $5(71.4)$ & - \\
\hline Using IFNc and RBV & 37 & $12(32.4)$ & $0.089^{a}$ \\
\hline Retreatments & 12 & $4(33.3)$ & - \\
\hline Using PEG-IFN and RBV & 10 & $4(40)$ & - \\
\hline
\end{tabular}

$a$ : Fisher exact test; IFNc: conventional interferon- $\alpha$ (IFNc); PEG-IFN: pegylated IFN; SVR: sustained virological response. 


\section{DISCUSSION}

This is the first study that analyses the efficacy of the treatment of chronic hepatitis C in MT. Similar studies have been conducted in the country's South and Southeast Regions, but this is the first one conducted in the Central-West Region. The results of these studies are shown in Table IV. Also included in Table IV are results from Phase 3 approval studies of PEG-INF to characterise the differences between experimental and postmarket studies.

Because the drugs that treat hepatitis $\mathrm{C}$ are very expensive, almost all patients, even those who receive treatment at private hospitals, access these drugs through the SUS. Therefore, we assume that the data presented in this study are representative of hepatitis C therapy in MT. In the present study, treatments administered in private hospitals and clinics did not achieve better SVR than those administered in public health institutions.

It was not possible to obtain information on 67 (25\%) of the 268 patients listed at the FAC-SSEMT as receiving these medications between 2002-2008, despite our attempts to contact via telephone the institutions in which they were treated, their physicians or even the patients themselves. In many cases, the information on these cases was lost due to changes of address or phone numbers, but it also demonstrates the unreliability of the medical records kept in healthcare institutions and hospitals in MT.

Some of the characteristics of the sample, such as age and the preponderance of both male subjects and genotype 1 , demonstrate that the present sample is similar to those from other series of clinical cases, which corroborates the results found and reduces the chance of a selection bias resulting from the loss of data (Zeuzem et al. 2000, Alves et al. 2003, Figueiredo-Mendes et al. 2003, Gonçales et al. 2006, Parise et al. 2006, Silva et al. 2007, Vigani et al. 2008, Almeida et al. 2009, McHutchison et al. 2009). Regarding genotype in particular, previous studies had already demonstrated that genotype 1 is predominant in MT, as it is in most of Brazil (Campiotto et al. 2005).

For the analysis of SVR rates, we considered 175 treatments that included RBV in the therapeutic regimen, excluding patients with HIV or renal failure, to make the population studied resemble those in similar studies. The SVR rate of $32.6 \%$ was lower than that observed in prospective studies, which report an SVR of approximately 50\% (Manns et al. 2001, Fried et al. 2002, Brandão et al. 2006, Gonçales et al. 2006, Silva et al. 2007), but similar to that observed in several retrospective studies in the country (Alves et al. 2003, FigueiredoMendes et al. 2003, Acras et al. 2004, Vigani et al. 2008, Almeida et al. 2009). These numbers suggest that in real-life conditions, the results obtained by the Brazilian healthcare services are not comparable to the results obtained in controlled trials, a fact that should be addressed by the country's public health authorities.

Cirrhosis was present in $19.4 \%$ of the 201 patients. Other national and international studies describe an incidence of cirrhosis ranging from 12-27\% (Manns et al. 2001, Fried et al. 2002, Alves et al. 2003, FigueiredoMendes et al. 2003, Gonçales et al. 2006, Parise et al.

\section{TABLE III}

Multivariate analysis of the influencing factors on the sustained virological response (SVR)

in the treatment of hepatitis $\mathrm{C}$ patients in the state of Mato Grosso, Brazil, considering only therapy regimens using ribavirin (RBV) and patients not infected with human immunodeficiency virus (HIV) or with chronic renal failure

\begin{tabular}{|c|c|c|c|c|}
\hline $\begin{array}{l}\text { Variables }^{a} \\
\text { (\% of SVR) }\end{array}$ & $\begin{array}{c}\text { Crude OR } \\
\text { ( } p \text { value) }\end{array}$ & $\begin{array}{l}\text { Adjusted } \\
\text { OR }\end{array}$ & $95 \% \mathrm{CI}$ & $\mathrm{p}$ value \\
\hline \multicolumn{5}{|l|}{ Treatment } \\
\hline Conventional IFN (27.1) & 1.0 & 1.0 & - & - \\
\hline Pegylated IFN (35.3) & $1.3(0.353)$ & 5.8 & $1.5-21.4$ & 0.008 \\
\hline \multicolumn{5}{|l|}{ Interruption } \\
\hline Yes (6.7) & 1.0 & 1.0 & - & - \\
\hline No (39.0) & $9.0(0.000)$ & 14.3 & $3.3-45.4$ & 0.000 \\
\hline \multicolumn{5}{|l|}{ Cirrhosis } \\
\hline Yes (15.2) & 1.0 & 1.0 & - & - \\
\hline No $(39.8)$ & $3.7(0.004)$ & 7.7 & $2.5-33.3$ & 0.002 \\
\hline \multicolumn{5}{|l|}{ Genotype } \\
\hline $1(27.8)$ & 1.0 & 1.0 & - & - \\
\hline Non-1 (37.5) & $2.5(0.295)$ & 5.3 & $1.7-16.7$ & 0.020 \\
\hline
\end{tabular}

a: logistic regression model using stepwise backward technique Stata 8.2 (Stata Corporation, College Station, Texas, USA, 2005), with 142 of the 175 treatments. Fifty-five treatments were excluded from the model due to patient infected with HIV, chronic renal failure, treatment schedules without RBV or lack of information on the genotype, age or cirrhosis. Other non-associated variables included in the model were gender, age, nature of the health institution where the treatment took place (public or private), other comorbidities (diabetes mellitus, porphyria, hyperthyroidism, psoriasis, psychosis) and whether it was the initial treatment or a retreatment; CI: confidence interval; IFN: interferon; OR: odds ratio; $p$ value of the model: $0.000 ;$ pseudo $\mathrm{R}^{2}: 0.17$. 
2006, Silva et al. 2007, Vigani et al. 2008, Almeida et al. 2009). Cirrhosis was one of the most important factors associated with treatment failure in our study, with only $15.2 \%$ of cirrhotic patients achieving an SVR (Table II).

The other variables associated with SVR, such as genotype 1, interruption of treatment and use of PEGIFN, were also as expected. Another fundamental factor, which unfortunately could not be analysed in this study due to incomplete treatment information, was the RBV dosage. In the past few years, it has become increasingly clear that a larger dose of RBV is linked to therapeutic success (Davis et al. 1998, Zoulin et al. 1998, Mangia et al. 2010).

The SVR rates in therapy regimens that included PEG-IFN and RBV were similar among initial treatments $(35.5 \%)$ and retreatments $(34.8 \%)$. The good out-

TABLE IV

Comparison of sustained virologic response (SVR) rates in other studies ${ }^{a}$ with those found in the present study

\begin{tabular}{|c|c|c|c|c|c|c|c|c|}
\hline $\operatorname{Site}^{b}$ & $\begin{array}{l}\text { IFN } \\
\text { type }\end{array}$ & $\begin{array}{l}\text { Total } \\
\text { (n) }\end{array}$ & $\begin{array}{l}\text { SVR } \\
(\%)\end{array}$ & $\begin{array}{c}\text { Gen } 1 \\
(\%)\end{array}$ & $\begin{array}{l}\text { Non-1 gen } \\
(\%)\end{array}$ & $\begin{array}{c}\text { Cirrhosis } \\
(\%)\end{array}$ & Type of study & Reference \\
\hline Multicenter international & $\begin{array}{l}\text { conv } \\
\text { peg }^{c} \\
\text { peg }^{d}\end{array}$ & $\begin{array}{l}505 \\
511 \\
514\end{array}$ & $\begin{array}{l}47 \\
54 \\
47\end{array}$ & $\begin{array}{l}67.9 \\
68.1 \\
67.8\end{array}$ & $\begin{array}{l}32.1 \\
31.9 \\
32.2\end{array}$ & 27 & $\begin{array}{c}\text { Naïve }^{e}, \\
\text { ITT, } \\
\text { RCT }\end{array}$ & $\begin{array}{c}\text { Manns } \\
\text { et al. (2001) }\end{array}$ \\
\hline Multicenter international & $\begin{array}{c}\text { conv } \\
\text { peg }\end{array}$ & $\begin{array}{l}444 \\
453\end{array}$ & $\begin{array}{l}44 \\
56\end{array}$ & $\begin{array}{l}62 \\
65\end{array}$ & $\begin{array}{l}38 \\
35\end{array}$ & 12 & $\begin{array}{c}\text { Naïve, } \\
\text { ITT, } \\
\text { RCT }\end{array}$ & $\begin{array}{c}\text { Fied } \\
\text { et al. }(2002)\end{array}$ \\
\hline Rio de Janeiro & conv & 202 & 30.2 & 71.6 & 28.4 & 15.3 & $\begin{array}{c}\text { Naïve, } \\
\text { observational }^{f}\end{array}$ & $\begin{array}{l}\text { Figueiredo-Mendes } \\
\text { et al. (2003) }\end{array}$ \\
\hline Rio Grande do Sul & conv & 337 & 32 & 41.3 & 58.7 & 45.3 & $\begin{array}{c}\text { Naïve, } \\
\text { ITT, } \\
\text { observational }\end{array}$ & $\begin{array}{c}\text { Alves } \\
\text { et al. }(2003)\end{array}$ \\
\hline São Paulo & $\begin{array}{l}\text { conv } \\
\text { peg }\end{array}$ & $\begin{array}{l}83 \\
97\end{array}$ & $\begin{array}{l}45.5 \\
36.2\end{array}$ & $\begin{array}{c}0 \\
100\end{array}$ & $\begin{array}{c}100 \\
0\end{array}$ & $\begin{array}{l}32.2 \\
15.3\end{array}$ & $\begin{array}{c}\text { Naïve, } \\
\text { observational }\end{array}$ & $\begin{array}{c}\text { Vigani } \\
\text { et al. (2008) }\end{array}$ \\
\hline Multicenter Brazil & peg & 134 & 33 & 72 & 28 & 34 & $\begin{array}{c}\text { Retreatment }^{e}, \\
\text { ITT, } \\
\text { RCT }\end{array}$ & $\begin{array}{c}\text { Parise } \\
\text { et al. }(2006)\end{array}$ \\
\hline Rio Grande do Sul & peg & 323 & 35.3 & 100 & 0 & 30.3 & $\begin{array}{c}\text { Naïve, } \\
\text { ITT, } \\
\text { observational }\end{array}$ & $\begin{array}{c}\text { Almeida } \\
\text { et al. (2009) }\end{array}$ \\
\hline Multicenter Brazil & peg & 67 & 54 & 60 & 40 & 10 & $\begin{array}{l}\text { Naïve, } \\
\text { ITT }\end{array}$ & $\begin{array}{l}\text { Gonçales } \\
\text { et al. (2006) }\end{array}$ \\
\hline Multicenter Brazil & $\begin{array}{l}\text { peg } \\
\text { conv }\end{array}$ & $\begin{array}{l}26^{g} \\
40^{h}\end{array}$ & $\begin{array}{l}62 \\
38\end{array}$ & $\begin{array}{l}73 \\
73\end{array}$ & $\begin{array}{l}27 \\
27\end{array}$ & $\begin{array}{c}5 \\
13\end{array}$ & $\begin{array}{c}\text { Retreatment, } \\
\text { ITT }\end{array}$ & $\begin{array}{l}\text { Gonçales } \\
\text { et al. (2006) }\end{array}$ \\
\hline Paraná & conv & 87 & 32.1 & 53.7 & 46.3 & 19.2 & $\begin{array}{c}\text { Naïve, } \\
\text { observational }\end{array}$ & $\begin{array}{c}\text { Acras } \\
\text { et al. }(2004)\end{array}$ \\
\hline São Paulo & peg & 58 & & 100 & 0 & $26^{i}$ & $\begin{array}{c}\text { Naïve, } \\
\text { ITT }\end{array}$ & $\begin{array}{c}\text { Silva } \\
\text { et al. }(2007)\end{array}$ \\
\hline Multicenter Brazil & peg & $\begin{array}{l}31 \\
54\end{array}$ & $\begin{array}{l}48 \\
76\end{array}$ & $\begin{array}{c}100 \\
0\end{array}$ & $\begin{array}{c}0 \\
100\end{array}$ & $\begin{array}{l}6.4 \\
9.2\end{array}$ & $\begin{array}{l}\text { Naïve, } \\
\text { RCT }\end{array}$ & $\begin{array}{c}\text { Brandão } \\
\text { et al. (2006) }\end{array}$ \\
\hline São Paulo & peg & 130 & 26.8 & 70 & 30 & 10.8 & $\begin{array}{l}\text { Retreatment, } \\
\text { ITT }\end{array}$ & $\begin{array}{l}\text { Gonçales } \\
\text { et al. (2010) }\end{array}$ \\
\hline Mato Grosso ${ }^{j}$ & $\begin{array}{c}\text { conv } \\
\text { peg }\end{array}$ & $\begin{array}{l}56 \\
93\end{array}$ & $\begin{array}{l}28.6 \\
35.3\end{array}$ & $\begin{array}{l}22.9 \\
90.4\end{array}$ & $\begin{array}{c}77.1 \\
9.6\end{array}$ & $\begin{array}{c}21.8 \\
25\end{array}$ & $\begin{array}{c}\text { Naïve, } \\
\text { observational }\end{array}$ & $\begin{array}{c}\text { Present } \\
\text { study }\end{array}$ \\
\hline Mato Grosso ${ }^{j}$ & $\begin{array}{c}\text { conv } \\
\text { peg }\end{array}$ & $\begin{array}{c}3 \\
23\end{array}$ & $\begin{array}{c}0 \\
34.8\end{array}$ & $\begin{array}{l}33.3 \\
54.5\end{array}$ & $\begin{array}{l}66.7 \\
45.5\end{array}$ & $\begin{array}{l}66.7 \\
43.5\end{array}$ & $\begin{array}{l}\text { Retreatment, } \\
\text { observational }\end{array}$ & $\begin{array}{l}\text { Present } \\
\text { study }\end{array}$ \\
\hline
\end{tabular}

$a$ : only studies which included treatment with RBV were considered. Studies performed on specific populations were excluded; $b$ : named localities are Brazilian states; $c$ : pegylated (peg) interferon (IFN) (1.5 mcg/Kg/week) for four weeks, afterwards 0.5 $\mathrm{mcg} / \mathrm{Kg} /$ week; $d$ : pegylated IFN (1.5 mcg/Kg/week) for the duration of the treatment; $e$ : naïve patients; $f$ : Phase 4 (observational); $g$ : relapser patients; $h$ : non-responder patients; $i$ : $26 \%$ of patients with F3 or F4; $j$ : excluded patients co-infected with human immunodeficiency virus or with chronic renal failure; conv: conventional; ITT: intention to treat; RCT: randomized controlled trial. 
comes of retreatments compared with initial treatments was likely because $23(88.4 \%)$ of the 26 retreatments were performed with PEG-IFN, most of them in patients who had received IFNc in their initial treatments.

However, when we analysed only the initial treatments of the non-1 genotype patients, $84 \%$ of whom were treated with IFNc, the SVR rate was $38.6 \%$. A multicentre study of retreatment in Brazil, conducted by Parise et al. (2006), had demonstrated good results. The SVR rate reached in the initial treatment of non-1 genotype with PEG-IFN (71.4\%) was higher than the SVR rate found in treatments with IFNc (32.4\%), although the difference was not statistically significant. Some of the initial treatments were performed with PEG-IFN, contrary to Brazilian Federal Administrative Rule 34/2007, probably because the medication was provided under a judicial injunction or because these were cirrhotic patients. These data support the use of pegylated IFN for all genotypes from the start of the treatment, as is performed in other countries (Ghany et al. 2009, Brook et al. 2010), thus sparing patients from the greater risk of therapy failure and the need for a new course of treatments.

In short, this study analyses aspects of the treatment of chronic hepatitis C in MT in the first decade of the 21 st century, showing SVR rates of approximately $30 \%$. Numbers similar to these were found in studies carried out in other regions of the country in real-life situations. The sum of these results indicates the need to re-evaluate the protocol of the Brazilian Ministry of Health for the purpose of improving the effectiveness of the program to control hepatitis $\mathrm{C}$ in the country.

\section{ACKNOWLEDGEMENTS}

To the sanitary authorities of the state of Mato Grosso, who authorized the access to the official files of the Farmácia de Alto Custo, and to the practitioners and health unities directors that allowed the access to the patient's medical files.

\section{REFERENCES}

Acras RN, Pedroso ML, Caum LC, Pisani JC, Amarante HM, Carmes ER 2004. The sustained response rates for chronic hepatitis C patients undergoing therapy with the several interferons and ribavarins supplied by Brazilian Health Ministry is comparable to those reported in the literature. Arq Gastroenterol 41: 3-9.

Almeida PR, Mattos AA, Amaral KM, Feltrin AA, Zamin P, Tovo CV, Picon PD 2009. Treatment of hepatitis C with peginterferon and ribavirin in a public health program. Hepatogastroenterology 56: 223-226.

Alves AV, Azevedo AP, Perin C, Ramos GZ, Brandão AB, Mattos AA, Almeida PR 2003. Tratamento de pacientes com hepatite crônica pelo vírus $\mathrm{C}$ com interferon alfa e ribavirina: a experiência da Secretaria de Saúde do Rio Grande do Sul. Arq Gastroenterol 40: 227-232.

Bedossa P, Poynard T 1996. An algorithm for the grading of activity in chronic hepatitis C. The Metavir Cooperative Study Group. Hepatology 24: 289-293.

Brandão C, Barone A, Carrilho F, Silva A, Patelli M, Caramori C, Focaccia R, Pereira L, Pedroso M, Tatsch F, Pessoa M, Pegasys Brazilian Study Group 2006. The results of a randomized trial looking at 24 weeks vs. 48 weeks of treatment with peginterferon alpha-2a $(40 \mathrm{kDa})$ and ribavirin combination therapy in patients with chronic hepatitis C genotype 1. J Viral Hepat 13: 552-559.
Brook G, Soriano V, Bergin C 2010. European guideline for the management of hepatitis $\mathrm{B}$ and $\mathrm{C}$ virus infections. Int $J$ STD AIDS 21: 669-678.

Campiotto S, Pinho JR, Carrilho FJ, Silva LC, Souto FJ, Spinelli V, Pereira LM, Coelho HS, Silva AO, Fonseca JC, Rosa H, Lacet CM, Bernardini AP 2005. Geographic distribution of hepatitis C virus genotypes in Brazil. Braz J Med Biol Res 38: 41-49.

Davis GL, Balart LA, Schiff ER, Lindsay K, Bodenheimer Jr HC, Perrillo RP, Carey W, Jacobson IM, Payne J, Dienstag JL, David H, Van Thiel V, Tamburro C, Lefkowitch J, Albrecht J, Meschievitz C, Ortego TJ, Gibas A, The Hepatitis Interventional Therapy Group 1989. Treatment of chronic hepatitis C with recombinant interferon alfa. A multicenter, randomized, controlled trial. Hepatitis Interventional Therapy Group. N Engl J Med 321: 1501-1506.

Davis GL, Esteban-Mur R, Rustgi V, Hoefs J, Gordon SC, Trépo C, Shiffman ML, Zeuzem S, Craxi A, Ling MH, Albrecht J 1998. Interferon alfa- $2 \mathrm{~b}$ alone or in combination with ribavirin for the treatment of relapse of chronic hepatitis C. International Hepatitis Interventional Therapy Group. N Engl J Med 339: 1493-1499.

Figueiredo-Mendes C, Cardoso C, Brandão-Mello CE, Pinto PT, Castro EJ, Pernambuco CD, Cardoso AC, Rosales FL, Milagre DR, Reis DM 2003. Eficácia do tratamento da hepatite crônica $C$ com interferon alfa- $2 \mathrm{a}$ ou $2 \mathrm{~b}$ e ribavirina entre pacientes de hospitais públicos da cidade do Rio de Janeiro. Gastroenterol Endosc Digest 22: 7.

Fried MW, Shiffman ML, Reddy KR, Smith C, Marinos G, Gonçales Jr FL, Häussinger D, Diago M, Carosi G, Dhumeaux D, Craxi A, Lin A, Hoffman J, Yu J 2002. Peginterferon alfa-2a plus ribavirin for chronic hepatitis C virus infection. N Engl J Med 347: 975-982.

Ghany MG, Strader DB, Thomas DL, Seeff LB, American Association for the Study of Liver Diseases 2009. Diagnosis, management and treatment of hepatitis C: an update. Hepatology 49: 1335-1374.

Gonçales Jr FL, Moma CA, Vigani AG, Angerami AF, Gonçales ES, Tozzo R, Pavan MH, Gonçales NS 2010. Retreatment of hepatitis $\mathrm{C}$ patients with pegylated interferon combined with ribavirin in non-responders to interferon plus ribavirin. Is it different in real life? BMC Infect Dis 10: 212.

Gonçales Jr FL, Vigani A, Gonçales N, Barone AA, Araújo E, Focaccia R, Oliveira U, Coelho HS, Paixao J, Perez R, Lobato C, Weirich J, Rosa H, Borges A, Vila R, Corrêa-Giannella ML, Ferraz ML 2006. Weight-based combination therapy with peginterferon- $2 \mathrm{~b}$ and ribavirin for naïve, relapser and non-responder patients with chronic hepatitis C. Braz J Infect Dis 10: 311-316.

Hadziyannis SJ, Sette Jr H, Morgan TR, Balan V, Diago M, Marcellin P, Ramadori G, Bodenheimer Jr H, Bernstein D, Rizzetto M, Zeuzem S, Pockros PJ, Lin A, Ackrill AM, PEGASYS International Study Group 2004. Peginterferon-alpha2a and ribavirin combination therapy in chronic hepatitis $\mathrm{C}$ : a randomized study of treatment duration and ribavirin dose. Ann Intern Med 140: 346-355.

Kim WR 2002. The burden of hepatitis C in the United States. Hepatology 36: 30-34.

Mangia A, Dalgard O, Minerva N, Verbaan H, Bacca D, Ring-Larsen H, Copetti M, Carretta V, Piazzolla V, Cozzolongo R, Mottola L, Andriulli A 2010. Ribavirin dosage in patients with HCV genotypes 2 and 3 who completed short therapy with peg-interferon alpha $2 \mathrm{~b}$ and ribavirin. Aliment Pharmacol Ther 31: 1346-1353.

Manns MP, McHutchison JG, Gordon SC, Rustgi VK, Shiffman M, Reindollar R, Goodman ZD, Koury K, Ling M, Albrecht JK 2001. Peginterferon alfa- $2 \mathrm{~b}$ plus ribavirin compared with interferon alfa- $2 b$ plus ribavirin for initial treatment of chronic hepatitis $C$ : a randomized trial. Lancet 358: 958-965.

McHutchison JG, Lawitz EJ, Shiffman ML, Muir AJ, Galler GW, McCone J, Nyberg LM, Lee WM, Ghalib RH, Schiff ER, Galati JS, 
Bacon BR, Davis MN, Mukhopadhyay P, Koury K, Noviello S, Pedicone LD, Brass CA, Albrecht JK, Sulkowski MS, IDEAL Study Team 2009. Peginterferon alfa-2b or alfa-2a with ribavirin for treatment of hepatitis C infection. N Engl J Med 361: 580-593.

Parise E, Cheinquer H, Crespo D, Meirelles A, Martinelli A, Sette H, Brazilian Pegasys Cooperative Study Group 2006. Peginterferon alfa-2a plus ribavirin in retreatment of chronic hepatitis $\mathrm{C}$ patients, nonresponders and relapsers to previous conventional interferon plus ribavirin therapy. Braz J Infect Dis 1: 11-16.

Poynard T, Marcellin P, Lee SS, Niederau C, Minuk GS, Ideo G, Bain V, Heathcote J, Zeuzem S, Trepo C, Albrecht J 1998. Randomized trial of interpheron alpha $2 \mathrm{~b}$ plus ribavirin for 48 weeks or for 24 weeks versus interpheron alpha $2 \mathrm{~b}$ plus placebo for 48 weeks treatment of chronic infection with hepatitis $\mathrm{C}$ virus. Hepatitis Interventional Therapy Group. Lancet 352: 1426-1432.

Sherman M, Yoshida EM, Deschenes M, Krajden M, Bain VG, Peltekian K, Anderson F, Kaita K, Simonyi S, Balshaw R, Lee SS, Canadian Pegasys Study Group 2006. Peginterferon alfa-2a (40 KD) plus ribavirin in chronic hepatitis $C$ patients who failed previous interferon therapy. Gut 352: 1631-1638.
Silva GF, Rodrigo RJ, Pardini MI, Corvino SM, Henriques RM, Peres MN, Silveira LV, Coelho KI 2007. Using pegylated interferon alfa- $2 \mathrm{~b}$ and ribavirin to treat chronic hepatitis patients infected with hepatitis $C$ virus genotype 1: are nonresponders and relapsers different populations? Braz J Infec Dis 11: 554-560.

Thomas DL, Seeff LB 2005. Natural history of hepatitis C. Clin. Liver Dis 9: 383-398.

Vigani AG, Pavan MH, Tozzo R, Gonçales ES, Feltrin A, Fais VC, Lazarini MS, Gonçales NS, Gonçales Jr FL 2008. Comparative study of patients with chronic hepatitis $\mathrm{C}$ virus infection due to genotypes 1 and 3 referred for treatment in Southeast Brazil. BMC Infect Dis 8: 164.

Zeuzem S, Feinman SV, Rasenack J, Heathcote EJ, Lai MY, Gane E, O'Grady J, Reichen J, Diago M, Lin A, Hoffman J, Brunda MJ 2000. Peginterferon alpha-2a in patients with chronic hepatitis C. N Engl J Med 343: 1666-1672.

Zoulin F, Haem J, Ahmed SS, Chossegros P, Habersetzer F, Chevallier M, Bailly F, Trépo C 1998. Ribavirin monotherapy in patients with chronic hepatitis $\mathrm{C}$ : a retrospective study of 95 patients. J Viral Hepat 20: 193-198. 